\title{
Wising Up: The Evolution of Natural Theology
}

The title of this chapter is a play on words, an adaptation and expansion of images and metaphors developed by Celia Deane-Drummond in her Boyle lecture and elsewhere, which I use as an entry point for reflecting on her theological proposals and their place within the broader context of the contemporary encounter between science and the Christian religion. ${ }^{1}$ In more than one sense, her work illustrates the "wising up" of theology which, also in more than one sense, has been and must continue to "evolve" within its own complex niche of overlapping ecclesial, social, and academic environments.

My response to Deane-Drummond has two parts. First, I call attention to the adaptive value and significance of her proposal, which I call "the sophianic theodrama hypothesis," for the ongoing development of Christian theological responses to the empirical findings and theoretical formulations within sciences such as evolutionary biology and psychology. In the second part, I outline some challenges to this way of proposing, challenges which, in my view, must be taken yet more seriously even - and perhaps especially - by those in the vanguard of theological engagement with the natural sciences. What further adaptation, if any, will be necessary for "natural" theology to survive within the competitive intellectual environment of the contemporary academy? Can it find (or construct) its own niche, or will it be compelled to migrate or adapt in some other way?

Or, must we finally admit that natural theology is an increasingly engangered species whose natural habitat is the church, and that it can only survive in the academy when ecclesial, political, and/or social conventions construct environmental protection areas within departments or professional associations in which the cognitive and coalitional biases of anthropomorphic promiscuity and sociographic prudery are sheltered and nurtured?

\section{The Sophianic Theo-drama Hypothesis as a Religious "Adaptation"}

My use of the term "adaptation" is not intended negatively in any way. The transmission of any tradition from generation to generation requires a balance

1 This chapter is an adapted version of "Wising Up: The Evolution of Natural Theology," which was originally published in Zygon: Journal of Religion \& Science 47, no. 3 (2012). That article was based on my response to Deane-Drummond's 2012 Boyle Lecture at St. Mary-le-Bow Church in London.

(C) F. LERON SHULTS, 2018 | DOI 10.1163/9789004360952_009

This is an open access chapter distributed under the terms of the CC BY-NC-ND 4.o license. Shu lts - 9789004360952 
between maintaining the integrity and coherence of the system and developing new functionally adequate responses to environmental changes. This also applies to the tradition of Christian theology, and the sub-tradition of "natural theology" within it, which has indeed evolved since the first Boyle lectures, and now must continue to adapt. Metaphorically speaking, we can think of Christian theological hypotheses as complex functional strategies for nourishing and nurturing a particular set of religious communities within a late modern scientific and philosophical environment that sometimes feels very hostile indeed.

Some might find it tempting to repeat fossilized formulations without engaging any scientific challenges, others to concede to any and all scientific challenges without concern for communal integrity. One path leads to the petrification, the other to the dissolution of the Christian tradition. As clearly articulated in her Boyle lecture, and further elaborated elsewhere, especially in Christ and Evolution: Wonder and Wisdom, ${ }^{2}$ Deane-Drummond takes the middle way between the twin temptations of ignoring and idolizing science. There is much wisdom in her approach - materially, as well as methodologically.

Deane-Drummond's material hypothesis is quite complex, but the central claim on which I will focus here can be summarized quite succinctly: Christians may interpret Jesus Christ as the dramatic expression of the Wisdom of God in a way that is compatible with contemporary evolutionary theory. The warrants and argumentation for this apparently simple claim are quite sophisticated. Her work is characterized by rigorous attempts to fulfill all four of what we might call the desiderata of constructive Christian theology: a faithful interpretation of the biblical witness, a critical appropriation of the theological tradition, a conceptual resolution of relevant philosophical issues, and a plausible elucidation of contemporary human experience.

Although it did not play a large role in her Boyle lecture, Deane-Drummond has argued elsewhere, in dialogue with current critical biblical scholarship, that early Christians interpreted Jesus in light of the Wisdom tradition of Hebrew literature. For example, in the Wisdom of Solomon, wisdom is portrayed as a feminine figure who fills all things and holds them together $(1: 6-7)$, who, more mobile than any motion, is creatively pervading and upholding all things (7:24-27). This language is applied to the risen Christ in the famous hymn of Colossians 1:15-20: “... for in him all things in heaven and on earth were created... all things have been created through him and for him. He himself is before all things, and in him all things hold together."

2 Deane-Drummond, Christ and Evolution: Wonder and Wisdom (Augsburg Fortress, 2009). 
Deane-Drummond also appropriates a vast array of resources from different streams within the Christian theological tradition, relying most heavily on Eastern Orthodox, Roman Catholic, and Anglican theologians. She is committed to maintaining the intuitions behind the Chalcedonian creed while still squarely facing the shift in what "fully human" means today in light of evolutionary theory.

She also exhibits a commitment to the last two desiderata: doing theology in a way that is intellectually and existentially responsible. Deane-Drummond offers careful arguments for her position, engaging relevant philosophical debates on issues such as causality, and links them to real concerns facing humanity as a whole such as the environmental crisis. Her integration of the sophianic and the dramatic, especially as developed by Hans urs von Balthasar, provides a way of attending more carefully to the element of tragedy within the human longing for wisdom that characterizes Homo sapiens. Elsewhere I too once argued, although not nearly so extensively, that utilizing the dynamic and relational language of the sophianic tradition appears to be the wisest strategy to adopt if one's goal is reconstructing the classical doctrines of Christology in dialogue with contemporary science. ${ }^{3}$

There are certainly objections internal to the Christian tradition that could be and ought to be raised. Some might worry that her proposal is a form of adoptionism. Others might regret her lack of attention to resources within other Protestant traditions. Some would be concerned that her emphasis on contingency easily lends itself to a rejection of divine omnipotence, or inadequately protects the distinction between God and the world. What about the problem of evil? Her sophianic theo-drama hypothesis deals respectfully with the tragedy of creaturely suffering but does not ultimately explain why an omnibenevolent being allows it.

Of course such concerns are not unique to Deane-Drummond's proposal; these are the kinds of problems with which all Christian theologians must wrestle. In my judgment, the general adaptive strategy she has developed is one of the only options available for contemporary theologians who want to remain within the Christian tradition. Rather than focus on these internal questions, however, in the second part of my response, I want to look at the adaptive task with a wider lens. What is happening to the niche within which theology, especially "natural" theology, is attempting to adapt? Exactly why and how - is it attempting to adapt within this niche?

3 Shults, Christology and Science (Wm. B. Eerdmans Publishing Co., 2008). That book was my last attempt to reformulate a Christian doctrine, before leaving behind what I now refer to as the sacerdotal trajectory of theology (see Chapters 6 and 7 above, and Theology After the Birth of God, Chapter 3$)$. 


\section{Is the "Natural" Niche of Christian Theology Shrinking?}

As I indicated in the first part of this chapter, theological hypotheses are a kind of religious adaptation. In other words, they are (whatever else they may be) strategies developed within religious coalitions to survive and thrive. The term "religious" is contentious in almost every environment, but I will continue to use it here in a way that is increasingly common among scientists in fields such as cognitive science, moral psychology, and cultural anthropology: shared imaginative engagement with axiologically relevant supernatural agents. As we have seen in earlier chapters, the disciplines that contribute to the bio-cultural study of religion offer compelling evidence that widespread ritual interaction with discarnate (or at least ontologically confused) intentional forces, which has been found in all known societies, is a result of evolved cognitive and coalitional biases.

In the sense we use the term today, "theology" emerged relatively late in human history, within complex literate states where unity of belief, ritual, and social identity was problematized by pluralistic encounters. During the axial age, the idea of an ultimate Supernatural Agency emerged in different ways across east, south, and west Asia. The mono-theistic construal of this Agency as a personal God is typical of the Abrahamic (west Asian) religions that trace their roots to this period. In Christian theology, affirming the transcendent intentionality of the one God is generally considered to be the basis for inclusion within (or exclusion from) one great Supernatural Coalition. In this sense, we could say that theology was an adaptive strategy that helped religious organizations unify, police, and transmit their preferred modes of imaginative supernatural engagement on a larger societal scale. Axial age religions provided the original and "natural" social niche within which theology evolved.

In another sense, however, theology - like science - is not "natural." Thinking scientifically - and theologically - is hard work, and requires extensive training; these intellectual engagement strategies must be cultivated. Thinking (as well as acting and feeling) religiously, however, is natural for many, if not most, people. Shared imaginative engagement with supernatural agents (or "gods") is common among human beings today because the cognitive and coalitional biases that promote such beliefs and behaviors are part of our shared phylogenetic inheritance.

As we have seen in earlier chapters, research in the disciplines that contribute to the bio-cultural study of religion suggests that gods are born in the human mind as a result of a wide array of cognitive mechanisms that engender belief in hidden agents when confronted with ambiguous or frightening phenomena. This first sort of mechanism helped (some of) our ancestors find (or avoid) important agents like predators, prey, protectors, or partners. However, 
the hypersensitivity of the cognitive tendency to detect intentionality also led to many false positives; faces are detected in clouds, ghosts in the shifting of shadows or smoke, divine blessing or punishment in unpredictable weather patterns, etc. But of course not all of these detected supernatural agents stick around.

Although gods may easily appear in the mental space of human life, it takes a village to nurture and care for them. In other words, supernatural agents must be borne in a special way within the social space of human life. The gods that stick around are typically those that are interpreted as having some social interest in and power over what happens within and to the in-group. Once detected, shared engagement with such gods - who may be watching in order to punish or reward - can lead to a decrease in cheating and defection to out-groups. This second sort of mechanism helps to explain inter alia the emergence of in-group altruistic behavior in a way that is consistent with natural selection. The cohesion of a group is protected when its members do not hurt one another, and are even willing to signal costly commitment to the coalition by hurting themselves (e.g., participating in painful rituals or other forms of self-sacrifice) or hurting members of out-groups (e.g., promoting exclusive or violent practices).

Empirical findings within the disciplines of the bio-cultural study of religion suggest that these detection/protection mechanisms come naturally to most people. So where does theology come in? Part of the "tragedy of the theologian" (to use Pascal Boyer's phrase) is that the vast majority of regular religious believers do not really need abstract doctrinal arguments about the incarnation of ultimate Supernatural Agents, for example, to hold together their everyday mental and social lives. Even if they can articulate the orthodox doctrine of an infinite and eternal God authorized by the church universal at Chalcedon, psychological studies (and a moment's reflection on our own experience as - or of - religious believers) show that under stress religious people's actual interpretation of events quickly collapse back into the detection of finite and temporally engaged supernatural agents (such as angels, saints or even the risen Jesus) who are interested in the protection of their own kith and kin. Those of us who have labored long in both academic and ecclesial environments know how difficult it is to get many believers to understand, or even to see the importance of, complicated doctrines like the incarnation.

\section{The Evolution of Natural(ist) Theology}

What does any of this have to do with the evolution of natural theology? Theology in general may have emerged in the axial age, but the environmental 
niche in which natural theology evolved was the competition of ideas within early modern science and philosophy, in which only the empirically sustainable and explanatorily powerful survived. Natural theology has traditionally been distinguished from revealed or confessional theology, which appeals explicitly to the detection of divine intentions (e.g., in a holy text), codifying and to some extent managing the coalition's shared engagement with its Supernatural Agent. This latter kind of theology serves an adaptive purpose, holding together the coalition in a more or less hostile social environment.

Now Deane-Drummond's project seems to blur the lines between revealed and natural theology; in my view, this distinction itself is a remnant of other ancient and modernist dualisms. However, we can still ask the question: in what niche and for what purpose does her sophianic theo-drama hypothesis operate? Her description of the task she has selected makes clear that her proposal is meant to function as a way of protecting the cohesion of (some parts of) the Christian tradition as it adapts to a changing conceptual environment. This frank acknowledgement that her natural theological efforts are intended to serve the church is refreshing.

But we might wonder about the viability of that other task, namely, the development of theological hypotheses that could function in the broader context of the academy or the public sphere as "defenses of Christianity in the wake of pressures from natural science." It seems to me that the latter would require argumentation that does not appeal directly or indirectly to controversial interpretations of the revelation of - or shared engagement with - the supernatural agents of one's own religious coalition. Otherwise, natural theologywould stillinvolve special pleading (as it always has). But are there any natural theological arguments that avoid such appeals? And if they could be developed, in what sense would they still be theological? Robert Boyle seems to have intuited these inherent tensions within natural theology when he indicated his desire that the original lectures series should not deal with controversies between Christians, i.e., with issues that might highlight - or even widen-fractures within the coalition.

Over the centuries, however, the conceptual environment within which such argumentation could be productive or even possible has been shrinking. Theologians who are concerned about the psychological and political health of Christian (or other) coalitions need to "wise up" to the fact that this academic niche is rapidly disappearing. Debates across the sciences and within the public sphere increasingly reject appeals to supernatural agency or coalitional authority in arguments about the causal nexus of the physical world or the normative organization of the social world. Many conservative Christian theologians and philosophers of religion have responded by forming their own enclaves within religious institutions. 
Deane-Drummond takes the more courageous approach. She describes her task as demonstrating the possibility of a compatibility between a reconstructed articulation of the doctrine of the incarnation and a scientifically responsible acknowledgement of the explanatory power of cutting edge evolutionary theory. As she explicitly notes, however, science itself has no need for such demonstrations of compatibility. Neither the academy nor the public sphere need natural theology. What, then, is the environmental niche within which such proposals can serve a (re)productive function? Are they necessarily limited to the Church - or a church? Can they only survive within private or public institutions that provide ecological sanctuaries for guilds of confessional theologians and religious professionals?

Deane-Drummond's work has consistently called our attention to the ecological crises of our world, and urged theologians to contribute to their resolution. ${ }^{4}$ As we have seen in earlier chapters, however, pouring fuel onto the firey imaginations of individuals and groups whose mental and social lives are saturated with anthropomorphically promiscuous and sociographically prudish intuitions can reinforce superstitious interpretations of the causes of (and solutions for) crises like global climate change. If theology is to contribute to real solutions to these sorts of problems, it will have to leave its sacerdotally sanctioned academic shelters and explore radically new options for a robustly natural-ist theology that follows what I referred to above as its iconoclastic trajectory: uncovering and resisting any and all sacred Images (icons) that pretend to mediate the supernatural agency or authority of a religious coalition.

4 See, e.g., Deane-Drummond, "Public Theology as Contested Ground: Arguments for Climate Justice," in Religion and Ecology in the Public Sphere (New York: T\&T Clark, 2011), 189. 